\title{
Making Sense of Ecopreneurs' Decisions to Sell Up
}

\begin{abstract}
This article examines the phenomenon of values-based firms being sold to larger mainstream firms. Its focus is on the sensemaking rationale offered by a New Zealand ecopreneur who sold an organic beverage company after twenty years at the helm. The company case study is presented through two enterprise development narratives based on alternative sensemaking modes. Key values-related challenges arising in ecopreneurial business are identified including: 1) adhering to the founder's values; 2) growing the business sustainably; 3 ) deciding whether and when to expand ownership to cope with undercapitalisation; 4) deciding who to bring in as new owners to ensure values alignment; 5) determining how and when the founder might leave; and 6) ensuring the attractiveness of the sustainability values so that they might be retained. Other factors implicated in the sale of values-based firms are also postulated. It is argued that although ecopreneurs might be accused of selling out their principles by selling up, there is some evidence that eco-brands are being maintained and growth prospects could be improved after acquisition. Serial ecopreneurship may even extend social benefits.
\end{abstract}

Keywords: ecopreneurship; enterprise development; sensemaking

Received 4 March 2010; as revised 21 December 2010, later published in Business Strategy and the Environment DOI: 10.1002/bse.710

Correspondence to: Professor Kate Kearins, Faculty of Business and Law, Auckland University of Technology, Private Bag 92006, Auckland, New Zealand. E-mail:

kate.kearins@aut.ac.nz

The authors acknowledge Dale Fitzgibbons in encouraging us to start out on this project and Kate Lewis's help in reviewing an earlier version of this article. 


\section{Introduction}

There seems to be a trend of established values-based firms selling up to larger mainstream firms. Some of the higher profile examples include Ben \& Jerry's, the socially-responsible ice-cream company, sold to Unilever in 2000. Nantucket Nectars was bought by CadburySchweppes in 2002, and Stonyfield Farm bought by Group Danome in 2003. In 2005, the organic fair trade chocolate company, Green \& Black, was sold to Cadbury-Schweppes, the world's biggest confectionery company. In 2006, The Body Shop, an icon of values-based business was bought by French cosmetics giant, L'Oréal. Tom's of Maine, best known for its all-natural toothpaste was sold to Colgate-Palmolive in the same year. Burt's Bees was bought by The Clorox Company in 2007 (see also "Who Owns Who" in Hollender and Fenichell, 2004). In 2008, accounting and consultancy company, Deloitte put out a report titled: How Green is the Deal? The Growing Role of Sustainability in M\&A, in recognition both of the growing trend and of the need to think through the issues involved.

The trend towards selling up is also evident among lesser known firms - and for us closer to home in New Zealand. In late 2005, Phoenix Organic, a beverage company inspired by a vision "to create a business that is good for the planet and good for the health of its people," was sold to mass market juice-maker Charlie's Group. This article focuses on Phoenix Organic's development through to its sale, and how the primary founder of that business - or ecopreneur - came to the decision to sell the business. We attempt to make sense of the broader phenomenon of ecopreneurs' decisions to sell up, by looking at 'frontstage' ecopreneurial sensemaking in the Phoenix Organic case a year after the sale, and by offering a 'backstage' view on how ecopreneurial sensemaking in this case changed over time.

In scoping this study, we claim it is still too early to determine whether many of the larger firms acquiring values-based businesses are able to really cash in on the "sustainability fad" (Zorn and Collins, 2007). However, other interesting questions arise in relation to the development of these values-based businesses and, in particular, the generation of early ecopreneurs' decisions to sell up - questions that are so far not addressed in the academic literature. These are the questions we address in this article:

- Why are the founders of values-based firms willing to sell up?

- Can ecopreneurs be accused of selling out their principles?

- Or, is it simply the right time for this early generation of ecopreneurs to move on? 
This article is structured as follows. First, a brief introduction to values-based firms and the particular class of businesses that might be considered ecopreneurial is provided, along with an overview of literature on ecopreneurship so as to provide an academic context and further rationale for this study. Second, the inherent challenges of ecopreneurial businesses are explored. Third the sensemaking approach which underpinned this study is briefly described. Fourth, we explain our actual research methods, including how we chose to collect, analyse and present data in the form of an enterprise development narratives which privilege alternative modes of sensemaking. Fifth and sixth, two such narratives, one 'frontstage' and one a 'backstage' narrative, are presented. The final section of the article modifies and extends understandings of challenges facing ecopreneurial businesses on the basis of the evidence provided in the Phoenix Organic case study. Our overall aim is thus to elucidate challenges in ecopreneurial enterprise development which might contribute towards an ecopreneur's decision to sell up.

\section{The nature of values-based business and the contribution of ecopreneurship literature}

Values-based businesses are not new, but they are a relatively recent focus for academic study beyond earlier small-scale studies and case exemplars often featuring businesses that have gained wider recognition or even attained an iconic status. While it might be argued that all businesses derive from, and potentially manifest, some sort of values-base, we focus here, in our use of the term 'values-based business' on those where the owners seek to make a positive difference to society through their business. Other related terms have emerged in this field. Social entrepreneurship, for example, seeks to align rational economic calculation and socially inspired vision (Roper \& Cheney, 2005). Another example is hybrid organizations, which are market-orientated and mission-centered and "are different from traditional forprofit and nonprofit organizations because their primary motivation is to use business and market forces as tools to solve the world's largest challenges" (Boyd et al., 2009 , p. 6). Closest to our own definition is that of Russo (2010, p.5) who refers to 'companies on a mission', using that term for those for-profit enterprises that seek "to simultaneously meet profit goals, and social and environmental goals that reflect the values of [their] owners". We note that with this notion of a values-based business, who actually owns the business is of importance in defining, allocating resources to, and achieving its mission. 
Within the broad class of values-based businesses are a smaller subset that we might consider to be ecopreneurial businesses. Typically they are led by an ecopreneur or small team of ecopreneurs who start the business in order to have a positive environmental and social impact, as well as make a profit. Definitional debates have persisted in the literature. We note our definition of ecopreneur is more modest than that offered by Anderson and Leal (1997, p. 3): "Entrepreneurs using business tools to preserve open space, develop wildlife habitat, save endangered species, and generally improve environmental quality". And it is considerably less radical and more inclusive than the definition relating to ecological or environmental entrepreneurship provided by Isaak $(1997$, p. 80$)$ as "system-transforming, socially committed environmental businesses characterised by breakthrough innovation.” In our view, while useful, such definitions would seem to exclude many businesses popularly seen as ecopreneurial, not least small businesses, and are more in line with notions of sustainable business, requisites for which can be found in Dyllick and Hockerts (2002) and Young and Tilley (2006).

We chose to focus on ecopreneurs as they are viewed as critical change agents needed to move toward a sustainable society (Anderson, 1998; Isaak, 1998; Larson, 2000; Pastakia, 1998). In establishing ecopreneurial businesses, they bring new products, technologies and services to market, and in the process attempt to change industry and consumer norms in favor of the environment and society.

The potential for positive environmental and social impact by businesses can be framed in two related but different ways. They can operate according to the business case for sustainability - which privileges a narrow, more entity-centered view which focuses on environmental and social enactments on the part of the company where they are perceived to also accrue financial benefit (e.g. reduced costs, enhanced revenues, reputation etc) (Dyllick, $\&$ Hockerts, 2002). Or, they can forgo some financial benefits and work for the greater good of the environment and society, taking a wider systems-oriented view of sustainability (Kearins, Collins \& Tregidga, 2010). It is the latter view that we tend to take, as theorists examining the potential for positive change in the environment and society, while acknowledging for investors and owners, the obvious appeal of the business case framing. Ecopreneurs would naturally tend to sit within the more systems-oriented camp, although there are clearly times in the development of their businesses when personal and/or financial 
priorities, and infrastructural impediments prevail over their working for the wider good, and the enactment of change.

Academic literature on ecopreneurship started to develop in the early 1990s, according to Schaper (2002). After a hiatus during the mid-1990s, the ecopreneurship concept re-emerged and, to a limited extent, coalesced with environmental and social entrepreneurship - and more recently what has been called "sustainable entrepreneurship" (Young and Tilley, 2006; see also the February 2009 special issue of Greener Management International on the topic of "sustainability entrepreneurship"). Although the ecopreneurship literature is growing with a number of books dedicated to it (e.g. Bennett, 1991; Schaper 2002 and 2005; Ivanko and Kivirist, 2008), and more research-based papers appearing, it is still relatively small (Walley and Taylor, 2002). In his edited book, Making Ecopreneurs, Schaper (2005) called for further definitional refinement, profiles, identification of barriers and triggers, and the development of research-based cases and quantitative studies to better understand the ecopreneurship phenomenon.

A major critique of ecopreneurship literature is that it has been overly speculative on the basis of relatively little empirical evidence (Gibbs 2009). Research producing typologies of ecopreneurs (Schaltegger, 2005; Walley and Taylor, 2002; Linnanen, 2002) has tended to be a prime focus, rather than work that tracks the development of ecopreneurial businesses (for an attempted exception, see Holt's (2009) study looking at the current status of the original ecopreneurial businesses identified in Bennett's 1991 book). A relevant critique of the more prevalent ecopreneurship typologies is that they are static and fail to account for changes over time as businesses and individuals develop (de Bruin and Lewis 2005). Research has not considered, for example, when priorities in the key dimensions of the Linnanen (2002) typology - such as ecopreneurial desire to change the world and financial drive - change. Challenges arising in developing and sustaining ecopreneurial business and the role of values therein, rather than the classification of types are our focus in the next section.

\section{Ecopreneurial values and inherent challenges}

This section draws further from academic literature in the field of ecopreneurship as well as from more popular accounts supplying examples to illustrate challenges salient to this class of business which might predispose ecopreneurs towards selling up. The review of the literature 
highlights several unique challenges for ecopreneurial businesses including their owners' propensity for trade-offs that often privilege environmental and social considerations at the expense of financial considerations (cf Hahn, Figge, Pinkse \& Preuss, 2010). Also traversed are the challenges of (market) growth and the strategic positioning of values-based entities post acquisition.

\section{Ecopreneurial values and the reluctance for financial trade-offs}

Ecopreneurs' personal values tend to be explicitly invested in their businesses from the outset. They identify environmentally responsible business opportunities in line with their values, and they develop new businesses and new ways to exploit them. The motivations for starting an ecopreneurial business thus typically align with the ecopreneurs' values and generally put "purpose and the planet before profits" (Ivanko and Kivirist, 2008, see also Isaac, 2002). Choi and Gray (2005) found the motivations of those they called sustainable entrepreneurs were, in the main, quite modest - starting businesses to make a living rather than to necessarily generate wealth or change the world. In their sample of 21 businesses, some business ideas were seen to originate "from the founders' drive to make a difference" (p. 4). In Allen and Malin's (2008) study, also, low levels of interest in economic success were a significant feature of the ecopreneur owners of the 10 businesses studied.

The values commitment is often seen as intrinsically tied to the founder and his/her ongoing involvement with the business. Importantly, ecopreneurs, or founders of what Robert Isaak (1998) calls "green-green" businesses, differ from those who attempt to green existing businesses (such as, for example Ray Anderson, founder of carpet tile manufacturer, Interface who went through a green epiphany). Isaak (1998) cites both The Body Shop and Ben \& Jerry's as examples of "green-green" businesses or "those that envision their business designs to be system-transforming, socially committed and technologically up-to-date breakthrough ventures" (p. 22). In Isaak's (1998) conception, the ecopreneur is a change agent, "with a strong sense of social mission, flexible imagination, a preoccupation with quality and an ultimate aim of giving back to the earth and the communities in which the businesses operate" (p. 49). Without the ecopreneur as champion, the business could easily renege on its sustainability values. 
The ecopreneur's choice and relative autonomy to prioritize activities in the wider interest that do not necessarily contribute financial benefit is an important component of ecopreneurial business. Roper and Cheney (2005, p. 99) maintain that the relative autonomy of the companies founded by those they call social entrepreneurs has "allowed for the consistent pursuit of social values - at times against the prevailing wisdom of financial analysts and in marked contrast to some competitors." Such reluctance to put finances first is at odds with the general direction of trade-offs suggested by Hahn et al (2010), where typically the business case prevails.

Petersen (2006) states the dominant strategy for ecopreneurial business is to claim a niche market position, which requires loyal, and, in the beginning at least, pioneer customers willing to pay for ecological benefits. Thus there needs to be some degree of synergy, or development thereof, between the ecopreneurial values at the heart of the business and those of the customer base. It may take some time, maybe even many years - and independent validation of product claims - to convince customers of the ecological value proposition. Put simply, at first - unless there are clear and generally immediate financial benefits for the customer, the customer, too, risks trading off ecological benefits.

\section{How big is big enough?}

It appears that growth may not be the primary goal for some ecopreneurial businesses. Concerns with social justice and community emerged, for example, in Allen and Malin's 2008 study of small ecopreneurial businesses. But for various reasons, including the fact that the current economic system favors large businesses and the cost savings realized from scale economies (Cato, Arthur, Keenoy and Smith, 2008), growth can still have very real appeal. Ecopreneurs can be tempted to diversify to achieve or increase growth, particularly if the core business is not bringing sufficient returns.

Growth may even be inimical to broader sustainability values. Outdoor gear and technical apparel company, Patagonia, for example, designed its long-lasting durable products for safety, dependability and performance rather than rapid repeat sales. The founder actually encouraged Patagonia's customers to reduce their purchasing of new products because of the social and environmental strain of producing, distributing, selling and disposing of new purchases (Chouinard, 2005). Hockerts (2003) points to the principle of sufficiency and the problems of fueling greater demand with consequential increased environmental impacts. 
In a related vein, Bo Burlingham's (2005) book, Small Giants: Companies That Choose to Be Great Instead of Big, profiles eight entrepreneurial businesses that chose a different path from the usual definition of business success. "We could grow faster, but it would cost us everything.... In the bureaucracy of growth, you lose your distinctiveness" (p. 156). The quote is from University National Bank \& Trust Co., a bank priding itself on fabulous service and oddball marketing that claimed to provide employees and the community with something more than a conventional bank. When the founder, Carl Schmitt, was ready to retire, the bank was sold to a large corporate. Burlingham relays the story as a cautionary tale. "Before the vote, Schmitt assured shareholders that Comercia would continue to maintain close ties to the community and provide first-class customer service, but the plain fact was that University National Bank \& Trust was disappearing into the maw of a giant corporation. It was never again quite the same" (p. 160).

Growth with founder champions losing influence and/or moving on and the potential loss of business distinctiveness and ecopreneurial values pose particular challenges. As in the entrepreneurship literature, there is a suggestion that the skills required to start up an ecopreneurial business are not the same skills required to manage the business if and when it matures. In a 2002 paper, Isaak suggests that Ben \& Jerry's and The Body Shop, which he had highlighted in his 1998 book as epitomizing ecopreneurial business, had lost some of their core values because they had grown too big:

The fact that both The Body Shop and Ben \& Jerry's became more preoccupied with corporate structure, compensation and legal issues than with the environment once their companies became established beyond a certain size does not distract from their ecopreneurial beginnings. It merely suggests that ecopreneurs may well be advised to go to start up other green-green companies rather than hanging on to one that enters an older, established 'maintenance' phase and that demands a trustee manager role more than an entrepreneurial influence. For sustainable development, the world needs 'serial ecopreneurs' (p. 83).

Growth for a values-based business has been said to only be able to occur at the "rate which it's able to train employees and management from within and integrate them into the corporate culture" (Cohen \& Warwick, 2006: p. 140). Such a suggestion raises issues around the sale of ecopreneurial businesses to larger firms as a mechanism for scaling up. 


\section{Selling up and maintaining the eco-brand}

It is useful to cite Petersen (2006) as a basis for discussing the critical point of when the ecopreneurial business is likely to be most attractive to buyers: "As long as the niche is small and insignificant for large-scale enterprises, there is little danger of being ousted from the market by imitators" (p. 409) - or becoming a captive company. As they become mature, however, Petersen points out ecopreneurial businesses may well start to look attractive to more established businesses which may have ignored an emerging technology, market, product or process up to this point. The challenge for ecopreneurs is in identifying when to sell up, or risk their business being taken over - ie the point at which they should, or can best capitalize personally on the hard work and risks taken in establishing the niche. The literature is relatively silent on this point.

We do know, however, that several of the acquiring companies have tended to leave the ecopreneurial business as a separate entity, quite distinct from the larger corporate brand. Mark Palmer, Marketing Director of Green \& Black commenting on the takeover by Cadbury states, "We've just had the first anniversary of the takeover and the amazing thing is that nothing has changed at all. In one sense, it was a bit of an anticlimax because absolutely nothing happened" (Walsh, 2006). Consumers too may notice little change. "I think the average person in a store thinks that Ben \& Jerry's ice cream is still being mixed by two guys in a Vermont barn" (Reidy, 2006).

In media publicity surrounding the recent acquisitions, the founders of some target companies suggest that selling up would allow their businesses to grow in ways their otherwise limited resources would not permit. They also claim that selling up could broaden the impact of their values-based businesses by positively influencing the acquiring companies - by way of a "Trojan horse" strategy. However, other commentators (e.g. Burlingham, 2005; Walsh, 2006) maintain ecopreneurs are overly optimistic about the survival of their core values after an acquisition. The limited data we have that traces ecopreneurial firms's status gives mixed results. Holt's (2009) research found 40 of the 94 original ecopreneurial businesses mentioned in Bennett's 1991 book appeared to have failed or closed down, others failed, some sold then failed, some sold but no longer operating, one sold then failed then back in business, and a few (5) sold and became a brand. The remaining 54 were represented across the traditional lifecycle stages, with the largest grouping (28) classified in the survival stage. Selling up may have some appeal but whether ecopreneurial brand independence, once achieved, is 
underpinned by broader sustainability values of the acquiring company post-acquisition, remains an open question.

In the next section we reflect on the relevance of the above-identified challenges to ecopreneurial sensemaking around the development and eventual sale of Phoenix Organic.

\section{Ecopreneurial sensemaking: An ongoing accomplishment}

We are particularly interested in what we call "ecopreneurial sensemaking." Sensemaking is an attempt to interpret and create an order or understandings that enables change (Weick, 1995). Sensemaking is particularly suited to this study because of the focus of sensemaking on ambiguity (Wieck, 2001). We are not the first researchers to see the fit between sensemaking and sustainability (see also Angus-Leppan, Benn, Young, 2010). In our study, there are the trade-offs that the founder of a value-based business is faced with, in developing and growing that business. The trade-offs might be seen to extend beyond environmental, social and financial dimensions.

We align ourselves with the notion that sensemaking is continuous. Feedback from learning provides new data for interpretation or reinterpretation (Angus-Leppan et al., 2010). In the Phoenix Organic case, the founder attempts to make sense of and reconcile competing values at various times across the development of the business and his sensemaking is a reflection of his construction of events at particular life-stages of the business. As Weick argued, "The basic idea of sensemaking is that reality is an ongoing accomplishment that emerges from efforts to create order and make retrospective sense of what occurs" (Weick, 1993a: 635).

The research on "traditional" entrepreneurs has tended to have an economic focus on value creation (an example of an exception is Cohen, Smith \& Mitchell, 2008). Ecopreneurs, on the other hand, as we stated earlier, are entrepreneurs who start businesses in order to have a positive environmental and social impact, as well as make a profit. We argue that ecopreneurs are generally interested in broader systems issues concerning sustainability, beyond the confines of the business itself as expressed in a regular business case approach. Their role is worthy of study because of the benefits wrought by their efforts - both direct benefits through the sale of ecologically and socially more responsible products and services and establishment of new market niches, and indirect benefits through their pioneering leadership. We make the 
case below for the utility of enterprise development narratives as useful entry points into ecopreneurial sensemaking.

\section{Case study sources and method}

In keeping with an inductive approach to theory generation and our social constructivist stance, we opted to present the Phoenix Organic case study through two enterprise development narratives. Mills and Pawson (2006) and Jones, Latham and Betta (2008) present enterprise development narratives from the perspective of a single entrepreneur, but not specifically from the point of view of an ecopreneur, as ours does. Our reason for adopting this approach is that there is likely to be several reasons behind the founding ecopreneur's decision to sell such a business, particularly after 20-years at the helm. We maintain that the context for the particular decision, and the events in the business's development leading up to the sale and the proffered sensemaking by the founding ecopreneur and the other owners at different times, are all important contributions to understanding the decision to sell up. Jones, Macpherson and Wollard (2008, p. 686) caution that how zorganisations evolve is "thoroughly embedded in locales and generalizations related to valuable assets or growth patterns much be made with great care." The way events and decisions are rationalized changes over time, according to both context and audience. While we cannot generalize from one case study, we believe that in identifying more general challenges and checking their applicability to this case, we can at least proffer tentative theoretical explanations for the wider phenomenon of values-based firms selling to larger firms.

The primary source utilized in the first enterprise development narrative was the most recent of three in-depth interviews with the founding ecopreneur, Chris Morrison, who oversaw the sale of Phoenix Organic. This interview took place in 2006, a year after the company had officially been sold, and during Morrison's final week with the acquired business, as part of a planned transition and takeover. Aligned with the sensemaking literature (Angus-Leppan et al., 2010; Weick, 2001), the interview highlights how Morrison made sense of the emergence and development of the business, to both rationalize events and inform organizational identity. It also shows how his sustainability values influenced decisions, in particular around the sale. 
Other sources, as noted below, informed the second enterprise development narrative presented here. There were the two formal interviews with Morrison that took place in the years prior to selling up - in 2004 and 2005, and informal discussions with him both before and after the sale. In 2004, the authors also interviewed other key members of the company: Roger Harris, co-owner and Director of Sales and Marketing; Rachel Brown, then employed part-time as Sustainability Director; and John Evans, Operations Manager. Morrison's wife, Deborah Cairns, also a co-owner, was interviewed in 2007, and confirmed her role at Phoenix Organic was secondary to Morrison's. Other sources referred to include company websites, press articles, and a teaching case we earlier wrote which had been sanctioned for release by Morrison (see Collins, Kearins \& Bowden, 2005/6).

The two enterprise development narratives are structured in line with a dramaturgical approach to understanding qualitative interviewing (Hermanns, 2004; Myers and Newman, 2007). The dramaturgical approach, drawing inspiration from the work of Erving Goffman $(1959 ; 1961 ; 1963)$, holds that social interactions generally follow familiar and predictable scripts. Enterprise development narratives, for example, are often based on chronological events and rational sequencing. Hence they can reflect life-cycle stage models as in the first narrative presented below - even though that theory has been criticized as a faulty basis for theoretical development (Levie and Lichtenstein, 2008). It is mainly Morrison's words that feature, with additional commentary given as context. As the primary founding ecopreneur, Morrison's narrative of how the business developed through to the point of its sale is one that can be seen as a front-stage performance (Goffman, 1963; see also Steyaert, 2004) in providing a public rationale for selling up. All quotes are from Morrison, and the content of this narrative were subsequently checked with him.

The second enterprise development narrative includes insights from the authors' previous interviews and subsequent conversations with Morrison, and from the other sources including from the cast of characters, noted above. Hence it is a more rounded and academic approach that is favored in this alternative sensemaking narrative wherein various challenges facing Phoenix Organic are focused on as less necessarily inherent in a life cycle chronology of birth, growth and maturity, as in the first narrative. Rather, in the second narrative they are presented thematically as a basis to endorse, amend or refute the generic challenges to ecopreneurial businesses identified in the literature reviewed above. The second narrative presents more of the backstage of organizational life (Goffman, 1963) to shed light on 
possible motivations and problems in adhering to sustainability values. Quotations are thus deliberately excluded. For ease of understanding and comparison across the two narratives, a similar structure tracing developments in the life of this ecopreneurial business is followed.

\section{Phoenix Organic - Morrison frontstage in his final week}

Chris Morrison had been working at a health-food store to support his naturopathy studies when he bought a ginger-beer business for \$NZ 50 in 1985 (Collins, Bowden \& Kearins, 2005/06). Twenty years later, the business - totally organic drink-maker Phoenix Organic sold for \$NZ 10 million to Charlie's Group, a New Zealand-owned juice company operating in Australia.

Morrison talked about his initial vision in founding the business, as "very open-ended." He had "no expectations, other than let's see if we can make a little bit of money out of this and have a bit of fun doing it.... I was interested in starting up something that had some ethical values that was socially responsible and environmentally sound." Morrison saw an opportunity to provide a healthy product in a market dominated by Coca Cola and Schweppes, with few natural products available apart from fruit juice. He and wife, co-owner, Deborah Cairns, mixed up early brews at home and took care of deliveries. Retailers in the early days had to handle the Ginger Fizz product carefully or risk it exploding. They brought in Roger Harris as a partner in the business in 1987, and he took over marketing to cafés and health stores.

Sustainability values inspired the business from the outset, according to Morrison who noted that the word "sustainability" was not really used then. Rachel Brown, then working for Waitakere City Council, helped put in place cleaner production and other systems to underpin what later became articulated as the business's sustainability plan. Phoenix Organic became the first New Zealand business to formally implement The Natural Step, a framework of science-based system conditions that assist movement toward sustainability.

The business's early growth necessitated moving into rented premises around 1987. Investment in pasteurization followed in 1988 which enabled the stabilization of the product. The range was then extended to include other natural beverages. According to Morrison, the business had "always been undercapitalized." The owners did not want to lose control, and so 
the business struggled financially in those early years. "We probably could have grown quicker with an injection of capital but we didn't want to compromise on our ideals. We didn't want someone else saying to us 'if you use plastic bottles instead of glass, you're going to make better margins and be able to get into supermarkets, or use preservatives and have a longer shelf life'.... It certainly held us back."

Early on, it was difficult to obtain a secure supply of organic ingredients - so the business focused on natural products at first, and concentrated on building stable supply relationships. "We were often paying up to $100 \%$ more for our raw materials and yet the consumers and the retailers were saying 'we are willing to pay $20 \%$ more for what we see as the premium on organic produce.' We've had to operate very efficiently and smartly.... Staying true to our values even when we were working very hard for not a lot of return has built up a very loyal customer base that has supported us and stuck with us all the way through has been a very important strategy for us - not to be tempted by cost-cutting and cheaper ways of doing things that would undermine our core beliefs in sustainability."

The business grew further after getting its products into supermarkets from around 1992. The owners eventually bought their own premises in 2000. A foray into other non-beverage organic products did not work out. Efforts to expand into Australia occurred but Morrison was not satisfied that the business had really cracked this neighboring export market. He saw huge growth potential, but admitted the business did not have the resources needed for a big push.

By 2005, Phoenix Organic was essentially a stable business, according to Morrison. Staff numbers were settled at around 25 to 30 . Phoenix Organic was finally able to deliver on its founder's earlier commitment to have its total product range certified organic. Morrison called it "a New Zealand iconic brand in this particular niche." He credited overseas events such as the bird flu and mad cow disease scares, along with the anti-genetic-engineering movement in New Zealand as external boosters of consumer interest in natural and healthy products, and the underlying production ethos around sustainability.

With Phoenix Organic's “position as a bit of a pioneer in the sustainability field," Morrison became a vocal advocate of business addressing social and environmental responsibilities. Morrison was chairman of the Auckland Environmental Business Network, and later the New 
Zealand Sustainable Business Network. He was on the board of internationally accredited New Zealand organic certification agency BioGro, becoming its vice chair. More recently he was elected to the Australia New Zealand Fairtrade Executive Committee. A month or so before Phoenix sold to Charlie's, John Evans, Phoenix's operations manager had bought into the business, in a bid to free up Morrison for the wider community interests he had developed. "It's a healthy thing for a business to get new blood coming through - that was the plan."

The approach from Charlie's Group to buy the business "came out of the blue, really." There had been some magazine publicity around Phoenix Organic, particularly in relation to its desire to expand into Australia. It resulted in a flurry of bankers, venture capitalists and potentially interested parties contacting the business. "People saw an opportunity there and they could see that business was growing.... Phoenix was poised ready to go the next level. I sent most of them away ... and then Charlie's came in one day and I thought they're not a bad fit - they're a New Zealand-owned company, they're in juice, they are smallish and they were really, really keen and they offered quite a reasonable price. It was a very clean deal, I just needed to stay on for one year - there weren't any onerous expectations or anything like that."

Morrison reflected, “This has been twenty years of my life - we've never really got anything out of it. Deborah has always worked either part-time or full-time and we've got kids that are growing up. It would be nice to get some of those things like a beach house and I just couldn't see it ever happening ... because every time you grow a little bit more you just keep plowing the money back in to the business... We just sat down and thought, 'You know - there are other things in life.' Phoenix is fantastic, and it's a very strong brand. Nobody's going to wreck that too much because it's very established ... and so I wasn't too concerned. Phoenix had reached a critical mass and there was consumer ownership of it."

Morrison's last year saw the amalgamation of Phoenix Organic into the Charlie's Group with the goal of beginning production of Charlie's products on the Phoenix Organics site in west Auckland in 2007. Charlie's strength in supermarkets complemented Phoenix Organic's in the café trade. Morrison predicted further international expansion. He liked the idea of localized manufacturing in new international markets - particularly given the costs "in shipping heavy glass bottles primarily full of water across the world." He hoped the Phoenix Organic brand would grow significantly - but acknowledged challenges involved in Phoenix Organic's new owners staying true to the business's values: "I'm confident that Phoenix has a really strong 
identity around sustainability and consumers buy into that and consumers will not let it deviate from that too much.” According to Morrison, when Charlie's looked at new products, its people were now thinking about packaging and synergies with Phoenix Organic products: "The debates about making cheap stuff or using preservatives are just not discussed now really - it's had a positive impact."

In the wake of the acquisition, Morrison's wife, Deborah Cairns co-founded a natural funeral business. Morrison intended to retain his interests in sustainability - having bought a $25 \%$ shareholding in eco-cleaning company BEE, and planning to work there two days a week. He was also keen to get into other ecopreneurial businesses. "To be involved in small start-up businesses has its own challenges and rewards, I do enjoy business and I'll be involved in little businesses along the way for sure.” Morrison was adamant sustainability values would underpin any new venture: “I wouldn't take on another business - and I don't have to - if it's not lined up with my personal values and the things that interest me and get me excited. It's a golden age for sustainability - you can get all negative about it, but at the same time there's opportunities there for New Zealand businesses because consumers are more and more educated, more and more reading labels and websites and more and more wanting to make ethical decisions in their purchasing."

\section{Phoenix Organic - Backstage}

Phoenix Organic was testimony to Morrison's ecopreneurial spirit in recognizing an opportunity in line with his values and in taking on substantial sustainability-related challenges that most other entrepreneurs back then shied away from. Morrison had surrounded himself with sympathetic and committed co-owners, who complemented his own skills. Phoenix Organic went well beyond compliance and was based on sustainability values consistently advanced by Morrison over the years, and largely endorsed by the co-owners. They also recognized and rewarded commitment by others. Rachel Brown who had earlier helped Phoenix Organic from her role in local government took a position on Phoenix Organic's board, and John Evans latterly shared in the ownership and profits from the sale.

Morrison's original ecopreneurial business idea was innovative and seemed to be ahead of its time. Sticking with it also involved the ongoing acceptance of risk. Phoenix Organic lacked a stable, large volume customer base for quite a few years. Supporting the values-base of the business cost more, particularly in regards to organic ingredients and glass bottles. Over time, 
supplies were made more secure with increased volumes being required and longer term supply relationships being fostered. Glass bottles were a huge cost - and unfortunately relegated to single use because of regulatory barriers. On its own, this small business could not influence many wider systems. Higher per unit costs comparative to other beverages meant Phoenix Organic's margins were squeezed, and along with investment in plant and equipment, inevitably contributed to lower profitability.

The business owners thus needed to be flexible in developing the business. Morrison's account of the business always being undercapitalized is entirely plausible and is consistent with his finding smarter ways of doing business, making savings from cleaner production and better systems. Rachel Brown's initially free advice in this respect fell on ready ears and the business was a willing guinea pig. The owners were clearly prepared to spend to support the values-base - and compromise their own lifestyles to keep the business growing. However, they did not want to kowtow to any new owner whose values might run counter to their own even if a new partner could have brought in much-needed capital.

Pursuing growth through internal firm developments was seen as a solution to the above conundrum. Selling to supermarkets and ultimately in larger take-home volume packs was an obvious device to increase sales - but supermarkets were fiercely competitive and shelf-space not easily won. After long signaling bottled water as an unnecessary evil, Phoenix Organic eventually added it to its product range, even though not everyone appeared to be happy with this decision. Diversification into other organic products did not bring the hoped-for returns. Resources were spread too thinly, and the business pulled back. The owners' attention refocused on the major international market next door. Shipping heavy glass bottles full of liquid was never ideal, nor a good fit with the espoused sustainability values and preference for supporting local produce and localized production. Phoenix Organic never had sufficient resources on the ground to really succeed with the Australian expansion, either.

The business had finally managed to achieve its founders' vision of going totally organic, but not without at least one hiccup - a Commerce Commission ruling about incorrect product labeling during a short-term supply glitch in a key organic ingredient. This example aside, a business espousing sustainability values and a fully organic product range was likely to attract high levels of scrutiny, and an ever-increasing range of expectations beyond what other businesses routinely face. In accepting that risk, and in furthering his vision, Morrison had 
indeed become a major champion of sustainable business in New Zealand, arguing the business case for sustainability. He rationalized relinquishing his commitment to Phoenix Organic as an opportunity to move on to new ecopreneurial ventures and a more familyoriented lifestyle, rather than as relinquishing any commitment to the wider sustainable business or ecopreneurial cause. His identity as a visionary ecopreneur was not in question.

Twenty years seems a long time for an entrepreneur to remain in one business. The original business idea had come along suddenly, and so had the opportunity and the decision to sell. An overall desire to see the business grow prevailed. The students of one us had pushed Morrison years ago on whether having done all the hard work in establishing the niche with few obvious rewards, the business might get picked off just when the product became popular. They - and the authors during the earlier interviews - had also raised the question of whether Morrison might be tempted to sell. Morrison's answers were generally consistent over the years. There were more challenges, he was enjoying the business - why get out? Then, a few months before the sale, he had responded that if a good offer came along, of course he would look at it. What Morrison meant by "good" was, of course, broader than just the price which he mentioned as reasonable. Charlie's seemed a "good" fit and had even earlier been mentioned by Morrison as a business Phoenix Organic could possibly work with. It facilitated the much-desired expansion.

The acquisition offer from Charlie's was well-timed for Morrison and his family, and apparently, in light of the difficulties in funding a big push, for the business too. Though Morrison was hopeful about what Charlie's would do next, there did not appear to be any guarantees. There were not many outward signs of major changes in what remained as the Phoenix Organic brand or the Charlie's business. The Phoenix Organic website had been professionally revamped - and though eco-elements were present, there was less evidence of a deeply-held commitment by way of a detailed sustainability plan. Charlie's had bought some strong eco-values and inherited management systems and processes for the Phoenix Organic products which promoted sustainability. But it was unclear whether these would extend across the whole Charlie's range. Outward signs of innovation at Charlie's included wood pulp labels sourced from managed plantations and certified to international composting standards (Charlie's, 2007) and more recently, the use of plastic water bottles made from plant sources, although these were not currently recycled. Notably, Charlie's had piggybacked on, rather than been involved in the development of the "eco-bottle". It was doubtful 
whether loyal Phoenix Organic customers would or could keep Charlie's faithful to the Phoenix Organic vision. New competitors had emerged in the organic beverage niche, and the bottle technology was being freely shared. The well-established processes at Phoenix Organic, the brand status, and the emergence of competition, we suspect, continued to drive Charlie's outward commitment to sustainability values, rather than any obvious customer outcry.

\section{Discussion}

Alternative sensemaking modes are represented in the above two narratives. The underpinning rationale of each is now analyzed in turn and integrated with the themes from the aforegoing review of literature and popular exemplars. In each narrative inevitably choices are made, and particular elements brought into focus, while others are de-emphasized.

In the first narrative, the plot line essentially runs from opportunistic but bold idea, through struggling start-up to small but cash-starved ecopreneurial business whose time has come, and whose owners might now deservedly reap the rewards for their efforts. It is an enterprise development narrative that ends with the sale of the business and opportunities to extend social benefits through serial entrepreneurship. Such a narrative that privileges sensemaking by the ecopreneur in the wake of the sale tells us only so much, however. Like other entrepreneur's accounts in media articles on the sale of their values-based businesses that we reviewed, it is a hopeful tale. In this instance, at that time, there was evident optimism around the future of the strong brand identity that the owners had worked hard to establish.

In the second narrative, the company was not presented as predictable nor stable, rather more as subject to both internal organizationally and owner-determined forces, as well as to wider external influences. The plot line is more complex, highlighting innovation in both the business idea and the visionary commitments Morrison had made to 'sustainable' business, more widely, and opportunism and acceptance of risk in both the start-up and the sale, as well as in other aspects of the business. The desire to retain ownership control and adhere closely to sustainability values was somewhat inimical to flexibility, and was again seen as restricting growth. But the sale was not seen to be unproblematic in ensuring an adherence to sustainability values. In this account, neither equilibrium nor progress were assured. The sensemaking in this second narrative is different. Challenges are not so much to be expected and overcome as part of a linear process towards growth; rather innovation, opportunism and 
risk-taking, flexibility and rewards appear more as entrepreneurial solutions to challenges. The question to be answered in the analysis that follows is how these challenges might lead to the decision to sell a strongly values-based business.

The earlier review of the literature and popular exemplars took little cognisance of the intertwining of the ecopreneurial business with the personal life course of the ecopreneur. Though it might take considerable time and effort for ecopreneurs to do justice to the challenges of ecopreneurial business, personal life course issues and choices almost inevitably intervene at some point. Massey, Harris and Lewis (2004, p. 1) note that despite an awareness of its importance, there has been "little research on the links between the business life-cycle model and the 'life-cycle' of the business owner - or on the relationship between personal 'life course' events and business milestones." How the ecopreneur's personal life course figures in considerations of business development is most evident in the ecopreneur's own narrative, and is worthy of further exploration in other cases. The point at which ecopreneurs decides that they have accomplished enough through the particular business and that the ecobrand is well-enough established has an obvious intersect with their desire to prioritize other life concerns, and to be free to exploit other opportunities. It also needs to intersect - of course - with the receipt of a worthy purchase offer to reward their efforts. Our point here is that personal life-course events and choices should not be ignored.

There should be little doubt that the ecopreneurs' personal values strongly influence the development of the business and the opportunities they might go on to exploit. The sustainability values-base of the niche ecopreneurial business is shown to present higher costs. With downwards pressure on prices to be competitive, and hence on margins, this values base may also contribute to ongoing under-capitalisation. Greater public interest in their products and processes may mean ecopreneurial businesses increasingly risk becoming captive to bigger players. With the evident attraction of increased scale, growth is shown to be a confounding issue, however. Loss of control by the founding ecopreneur could see values compromised when the business is sold. However, the proceeds of a sale can open up other business opportunities which the successful ecopreneur may be well-placed to lead.

Consideration of the growth conundrum for ecopreneurial businesses is also in order. Concentration on a single product range across more markets was the most appealing strategy in the Phoenix Organic case to grow the ecopreneurial business so that satisfactory financial 
returns could be achieved. This strategy did not incur new organic supply challenges or problems in achieving eco-efficiency, or customer scrutiny across a wider brief. The proven recipe could be repeated. However, horizontal integration across geographically distant markets does raise other challenges for a business espousing sustainability values. Without local production, transportation of products to the new market has inevitable environmental impacts. Sustainable production requires proximity to both supplies and markets - which, taken together, might well work against expansion. The acquisition of Phoenix Organic by Charlie's, providing the opportunity to produce in both local markets, was a solution in this case. However, ultimately, even if the products are less environmentally-damaging alternatives, the question of whether they are actually necessary and whether their consumption should be encouraged still arises. Weinberg (1998) discusses the paradoxical tension for green businesses: growth is what makes them significant particularly in replacing competitors' unsustainable practices, but businesses find it difficult to grow and stay green. He points to issues of labour intensity, quality control and resulting ecosystem disruption from increased production and waste. The most confounding challenge of all for ecopreneurs may well be whether growth can actually be sustainable.

How to best ensure the values base is both attractive to a buyer and will be retained after sale is a further challenge. Without continuing formal influence by the ecopreneur, there were no guarantees that Charlie's would maintain or expand the values-base as pointed up most clearly in the second narrative. Morrison claimed that his belief in Phoenix Organic's customers' loyalty gave him greater comfort level regarding the sale of the business. Here, as in other cases earlier reviewed, the brand remained intact. However, seeing the business as essentially stable ignores the flexibility the acquiring firm may well recognize in opportunities presented through ownership. How to inspire ongoing customer vigilance over eco-brand values without creating sustainability challenges that the business cannot currently or consistently address is an open question. Such additional scrutiny and expectations could conceivably render a business unattractive to a buyer, uncompetitive or even impossible to sustain.

To align with ecopreneurial values, who to sell to seems to be extremely important, as well as when. Morrison was earlier reluctant to expand ownership to bring in much-needed capital and risk loss of ecopreneurial autonomy to prioritize activities in the wider interest that do not necessarily contribute financial benefit. This reluctance is partly explicable in terms of 
both the then less-well-developed values implementation and establishment of a profitable niche. Rather than suggesting the stability stage as the logical time to affect a sale, the second narrative in particular suggests that at various points in the business development, business owners may seek new opportunities for growth, and may be more amenable to risk. Graebner and Eisenhardt (2004) also point to strategic and emotional factors as well as timing being important in selling up, not just price. This challenge may be summarized as to whether and when to expand ownership, and to whom and on what basis to assure values alignment and to cope with undercapitalization.

Figure 1 summarizes the specific values-related challenges raised in our earlier review and in the above analysis of the Phoenix Organic case.

\section{Figure 1}

\section{Values-related Challenges in Ecopreneurial Business}

Adhering to the founder's sustainability values

Growing the business sustainably

Deciding whether and when to expand ownership to cope with undercapitalisation Deciding who to bring in as new owners to ensure values alignment

Determining how and when the founder might leave

Ensuring the attractiveness of the sustainability values so that they might be retained after the founder leaves

\section{Conclusion}

This paper makes a contribution to understanding ecopreneurial business development in two main ways. First, we have presented and compared alternative enterprise development narratives rationalising the events leading to the sale of an ecopreneurial business. Values adherence is underscored in both narratives. Second, we have identified a range of challenges specific to the values-based ethos of ecopreneurial business. These challenges, we suggest, may not be necessarily resolved over time through any staged progression or logical development of the business that might be represented in ecopreneurial sensemaking. We sought to focus attention on challenges facing ecopreneurial business by bringing in more perspectives and a more dynamic interplay of entrepreneurial elements in an alternative semsemaking mode. We also pointed up perhaps intractable challenges inherent in ecopreneurial business that may not be resolved through selling up. It is acknowledged that a more critical analysis informs the second enterprise development narrative. 
We now answer each of our earlier questions on the basis of the analysis of the Phoenix Organic case, as well as our review of the wider literature and popular exemplars.

Our first question asked why the founders of values-based firms are willing to sell up. We suggest it is a combination of factors relating to the values-related challenges we identified above, as well as people and context specific factors pertaining to the particular case that influence the development and the sale of such businesses. Key people factors include the ecopreneur's lifecourse and choices, and the extent to which sustainability values might be perceived by the ecopreneur to penetrate the acquiring firm. Contextual factors include the wider public awareness and interest in sustainability values which might underpin the ongoing growth potential and attractiveness of ecopreneurial business. Less focused on in our analysis is purchaser opportunism and price - but we postulate these are also important factors in any decision to sell up.

Our second question was whether ecopreneurs could be accused of selling out their principles. Our analysis points to the possibility of ecopreneurial businesses continuing on a perhaps different trajectory after their sale, and/or the departure of the founding ecopreneurs. Lack of progress or even the possibility of decline may be averted by the possibility of enhanced growth through the new investment made in the business, and the new opportunities perceived by a different owner with perhaps different priorities. However, the Phoenix Organic case study and all the examples we reviewed present the complicating factor of whether sustainability values endure after acquisition and the departure of a key founding ecopreneur. Ecopreneurial brand survival is one evident indication. However the possibility of a new direction, while not unique to an ecopreneurial businesses selling up, poses a direct threat to its ecopreneur-inspired values base. And the extent to which sustainability values penetrate the acquiring businesses is, at present, not the subject of known research. That others from this early wave of ecopreneurs may, like the ecopreneur in the Phoenix Organic case study, go on to pursue even more potentially impactful opportunities on the broader sustainability front is worthy of consideration. Selling up? Yes. Selling out? In this case, no. The potential impact of the owners' principles could be broadened, and social benefits gained through serial ecopreneurship. 
Our final question was whether it was simply the right time for this early generation of ecopreneurs to move on. This question is harder to answer. In the Phoenix Organic case, it seemed so. In that case and in others we looked at, the answer to our first question above appears as an obvious way to obfuscate here. A number of factors appear to combine to make the decision to move on, one that seems rational. The early generation of ecopreneurs - some of them former hippies and perhaps part of the people's movements of the 1960s and 1970s, were undoubtedly inspired and some may be so again, in different contexts. Others may justifiably be ready to retire, and/or to live an easier life.

Finally, we note a focus for future research, and that is whether the businesses founded by this early generation of ecopreneurs, and others following them, survive intact after being sold up. Other issues identified here requiring further explication across a range of cases are the additional costs involved in, and expectations of ecopreneurial businesses, and the resultant pressure on margins. Both careful development of eco-brands and achieving scale are clearly important. Cracking the growth conundrum remains a challenge for ecopreneurial business and one that merits additional sense-making that extends beyond the decision to sell up.

\section{References}

Allen JC, Malin S. 2008. Green entrepreneurship: a method for managing natural resources? Society \& Natural Resources 21(9): 828-844.

Anderson AR. 1998. Cultivating the Garden of Eden: Environmental entrepreneuring. Journal of Organizational Change Management, 11(2): 135-144.

Anderson TL, Leal DR. 1997, Enviro-capitalists: Doing Good While Doing Well, Lanham: Rowan and Littlefield.

Angus-Leppan T, Benn S, Young L. 2010. A sensemaking approach to trade-offs and synergies between human and ecological elements of corporate sustainability. Business Strategy and the Environment, 19(4): 230-244

Bennett, S. J. (1991). Ecopreneuring: The Complete Guide to Small Business Opportunities from the Environmental Revolution. New York: John Wiley.

Boyd B, Henning N, Reyna E, Wang DE, Welch, MD. 2009. Hybrid Organizations: New Business Models for Environmental Leadership. Greenleaf: Sheffield

Burlingham B. 2005. Small Giants: Companies That Choose to Be Great Instead of Big, Penguin: New York.

Cato MS, Arthur L, Keenoy T, Smith R. 2008. Entrepreneurial energy: associative entrepreneurship in the renewable energy sector in Wales. International Journal of Entrepreneurial Behaviour \& Research 14(5): 313-329.

Charlie's, 2007, October 10. Charlie's News: compost your Charlie's. www.charlies.co.nz/\# Accessed 26 October 2007. 
Choi DY, Gray ER. 2005. The Venture Development Processes of 'Sustainable' Entrepreneurs. www.sbaer.uca.edu/research/usasbe/2005/pdffiles/papers/12.pdf Accessed 9 January 2007.

Chouinard Y. 2005. Let My People Go Surfing: The Education of a Reluctant Businessman. Penguin: New York.

Collins E, Bowden S, Kearins K. 2005/2006 Winter. Phoenix Organic: valuing sustainability while desiring growth. Business Case Journal 13(2) 77-98.

Cohen, B \& Warwick M. 2006. Values-driven Business: How to Change the World, Make Money, and Have Fun. Berrett-Koheler: San Francisco.

Cohen B, Smith B, Mitchell, R. 2008. Toward a sustainable conceptualization of dependent variables in entrepreneurship research. Business Strategy and the Environment 17(2) 107-119.

de Bruin A, Lewis K. 2005. Green entrepreneurship in New Zealand: a micro-enterprise focus, in Schaper M. (ed). Making Ecopreneurs: Developing Sustainable Entrepreneurship, Ashgate: Aldershot, pp. 61-71.

Deloitte 2008. How Green is the Deal? The Growing Role of Sustainability in M\&A. www.deloitte.com/dtt/cda/doc/content/How_Green_Is_the_Deal.pdf, accessed 1 March, 2009.

Down S, Warren L. 2008. Constructing narratives of enterprise: clichés and entrepreneurial self-identity. International Journal of Entrepreneurial Behaviour \& Research 14(1): 423.

Dyllick T, Hockerts K. 2002. Beyond the business case for corporate sustainability. Business Strategy and the Environment 11(2): 130-141.

Gibbs D. 2009. Sustainability entrepreneurs, ecopreneurs and the development of a sustainable economy. Greener Management International 55: 63-78.

Goffman E. 1959. The Presentation of Self in Everyday Life. Anchor Books: Garden City.

Goffman E. 1961. Encounters. Bobbs-Merril: Indianpolis.

Goffman E. 1963. Behavior in Public Places: Notes on the Social Organization of Gatherings. Free Press: New York.

Graebner, ME, Eisenhardt K. 2004. The seller's side of the story: acquisition as courtship and governance as syndicate in entrepreneurial firms. Administrative Science Quarterly 49(3): 366-403.

Hahn T, Figge F, Pinkse J, Preuss L. 2010. (Editorial) Trade-Offs in Corporate Sustainability: You Can't Have Your Cake and Eat It. Business Strategy and the Environment 19(4): 217-229.

Hermanns H. 2004. Interviewing as an activity, in Flick U, von Kardorff E, Steinke I. (eds). A Companion to Qualitative Research. Sage: London, 209-213.

Hockerts KN. 2003. Sustainability Innovations, Ecological and Social Entrepreneurship and the Management of A Hermanns ntagonistic Assets. Unpublished PhD Thesis, University of St Gallen.

Hollender J, Fenichell S. 2004. What Matters Most: How a Small Group of Pioneers is Teaching Social Responsibility to Big Business, and Why Big Business is Listening. Basic Books: New York.

Holt D. 2009. Where are they now? Evaluating Bennett's ecopreneurs. Academy of Management Meetings, Chicago, USA.

Isaak R. 1997. Globalisation and green entrepreneurship. Greener Management International 18: 80-90.

Isaak R. 1998. Green Logic: Ecopreneurship, Theory and Ethics. Greenleaf: Sheffield.

Isaak R. 2002. The making of the ecopreneur, Greener Management International 38: 81-91. 
Ivanko JD, Kivirist L. 2008. Ecopreneuring: Putting Purpose and the Planet before Profits. New Society: Gabriola Island BC, Canada.

Jones O, Macpherson A, Wollard D. 2008. Entreprenurial ventures in higher education: analysing organizational growth. International Small Business Journal 26(6): 683-708.

Jones R, Latham J, Betta M. 2008. Narrative construction of the social entrepreneurial identity. International Journal of Entrepreneurial Behaviour \& Research 14(5): 330345.

Kearins K, Collins E, Tregidga, H. 2010. Beyond corporate environmental management to a consideration of nature in visionary small enterprise, Business and Society, 49(3): 512-547.

Larson A. 2000. Sustainable innovation through an entrepreneurship lens. Business Strategy and the Environment 9: 304-317.

Levie J, Lichtenstein BB. 2008. From 'stages' of business growth to a dynamic states model of entrepreneurial growth and change. University of Strathclyde Hunter Centre for Entrepreneurship Working Paper WP08-02.

Linnanen L. 2002, An insiders' experience with environmental entrepreneurship. Greener Management International 38: 71-80.

MacPherson A, Jones O, Zhang M. 2004. Evolution or revolution? Dynamic capabilities in a knowledge-dependent firm. R\&D Management 34 (2): 161-177.

Massey C, Harris C, Lewis K. 2004. Death, divorce and disease: Personal life events and the business life-cycle. RENT XVIII Managing Complexity and Change in SMEs Conference, Copenhagen.

Mills CE, Pawson K. 2006. Enterprising talk: a case of self construction. International Journal of Entrepreneurial Behaviour \& Research 12(6): 328-344.

Myers M, Newman M. 2007. The qualitative interview in IS [Information Systems] research: examining the craft. Information and Organization 17(1): 2-26.

Pastakia A. 1998. Grassroots ecopreneurs: Change agents for sustainable society. Journal of Organizational Change Management 11(2): 157-169.

Petersen H. 2006. Ecopreneurship and competitive strategies: striving for market leadership by promoting sustainability, in Schaltegger S, Wagner M. (eds). Managing the Business Case for Sustainability: The Integration of Social, Environmental and Economic Performance, Greenleaf, Sheffield, 398-411.

Phoenix Organic. 2005. Phoenix Vision. www.phoenixorganic.co.nz Accessed 10 May 2005.

Reidy C. 2006, March 22. Colgate will buy Tom's of Maine: $\$ 100 \mathrm{~m}$ deal may help boost sales of leader in natural products niche. The Boston Globe www.boston.com Accessed 16 October 2006.

Roper J, Cheney G. 2005. The meanings of social entrepreneurship today. Corporate Governance 5(3): 95-104.

Russo M. 2010. Companies on a Mission: Entrepreneurial Strategies for Growing Sustainably, Responsibly, and Profitably. Stanford CA: Stanford University Press.

Schaltegger S. 2005. A framework and typology of ecopreneurship: leading bioneers and environmental managers to ecopreneurship, in Schaper M. (ed). Making Ecopreneurs: Developing Sustainable Entrepreneurship. Ashgate: Aldershot, 43-55.

Schaper M. 2002. The essence of ecopreneurship, Greener Madnagement International 38 (Summer): 26-30.

Schaper M. (ed). 2005. Making Ecopreneurs: Developing Sustainable Entrepreneurship. Ashgate: Aldershot.

Steyaert CK. 2004. The prosaics of entrepreneurship, in Hjorth D, Steyaert C. (eds). Narrative and Discursive Approaches in Entrepreneurship, Edward Elgar: Cheltenham, 8-21. 
Steyaert CK 2007. 'Entrepreneuring' as a conceptual attractor? A review of process theories in 20 years of entrepreneurship studies. Entrepreneurship and Regional Development, 19(November): 453-477.

Walley L, Taylor D. 2002. Opportunists, champions, mavericks...? A typology of green entrepreneurs. Greener Management International 38: 31- 43.

Walley F. 2006, June 8. Ethical consumers when big business bites: can niche firms keep their fans when snapped up by the multinationals? The Guardian.

Weick KE. 1993. The collapse of sensemaking in organisations: the Mann Gulch disaster. Administrative Science Quarterly 38(4): 628-652.

Weick, K. E. 1995. Sensemaking in organizations. Thousand Oaks, CA: Sage.

Weick KE. 2001. Making Sense of the Organization. Blackwell: Oxford.

Weick KE, Sutcliffe KM, Obstfeld D. 2005. Organizing and the process of sensemaking. Organization Science 16(4): 409-421.

Weinberg AS. 1998. Distinguishing among green businesses: Growth, green and anomie. Society and Natural Resources 11: 241-250.

Young W, Tilley F. 2006. Can businesses move beyond efficiency? The shift toward effectiveness and equity in the corporate sustainability debate. Business Strategy and the Environment 15 (6): 402-415.

Zorn T, Collins E. 2007. Is sustainability sustainable? CSR, sustainable business, and management fashion, in May S, Cheney G, Roper J. (eds). The Debate over Corporate Social Responsibility. Oxford: New York, 405-416. 